\title{
Obciążenie opiekunów nieformalnych a sprawność funkcjonalna i umysłowa pacjentów objętych opieką domową
}

\author{
The informal caregivers' burden related to the mental and functional performance \\ of the patient undergoing home care
}

\author{
Alina Deluga, Agnieszka Bartoszek, Barbara Ślusarska, Katarzyna Kocka, Grzegorz Nowicki, \\ Katarzyna Piasecka, Hanna Kachaniuk
}

Uniwersytet Medyczny w Lublinie, Zakład Medycyny Rodzinnej i Pielęgniarstwa Środowiskowego, Katedra Onkologii i Środowiskowej Opieki Zdrowotnej, Wydział Nauk o Zdrowiu, ul. Staszica 4-6, 20-081 Lublin

Medical University of Lublin, Department of Family Medicine and Community Nursing

$\bowtie$ alina_deluga@poczta.onet.pl

\begin{abstract}
Introduction: Family members as informal caregivers are the most common and important providers of caring services in the home environment of patients suffering from chronic diseases. The aim of the study was to assess the relationship between the functional and mental performance of patients being provided long-term nursing home care and the burden of their caregivers. Materials and methods: The study was carried out in the Lublin region from September 2016 to February 2017. The study group included 149 patients with chronic diseases under long-term nursing home care and their 150 informal caregivers. The burden of the caregivers was assessed by means of the Carers of Older People in Europe (COPE) Index questionnaire which is used to check different aspects of the caregivers' roles, life situations and relationships with the care recipients. The patients functional performance was measured by means of the Barthel Index for Activities of Daily Living, while their mental performance was checked using the Abbreviated Mental Test Score.
\end{abstract}

Results: According to the COPE Index, the caregivers' burden for particular subscales was as follows: Negative Influence of Care (NIC) 11.80 (SD = 3.75), Positive Value of Care (PVC) 13.71 (SD = 2.07), Quality of Support (QS) 12.46 (SD = 2.69). It has been indicated that the worse the functional and mental performance of the patient under care, the greater the burden of the carers NIC $(p<0.01)$, the lower the satisfaction with care - PVC $(p<0.01)$ and the lower the quality of support given $-\mathrm{QS}(\mathrm{p}<0.01)$. The deterioration of a patient's mental performance correlates with the female gender of the caregiver and the longer duration of care. Conclusions: The lower functional and mental performance of patients who are being provided long-term nursing home care has a relationship to the experience of the negative effects of care by informal carers, lower satisfaction with care and lower quality of support.

Keywords: burden; caregiver; home care; patient; performance deficiency.

\section{ABSTRAKT}

Wstęp: Rodzina i jej członkowie jako opiekunowie nieformalni są najpowszechniejszym i najważniejszym dostawcą usług opiekuńczych dla pacjentów przewlekle chorych, przebywających w środowisku zamieszkania.

Celem badania była ocena związku sprawności funkcjonalnej i stanu umysłowego pacjentów objętych pielęgniarską opieką długoterminową domową z obciążeniem opiekunów.

Materiały i metody: Badania przeprowadzono w województwie lubelskim w okresie od września 2016 do lutego 2017 r. Grupę badanych tworzyło 149 pacjentów z chorobami przewlekłymi objętych pielęgniarską opieką długoterminową domową oraz 150 opiekunów nieformalnych. Do oceny obciążenia opiekunów użyto kwestionariusza COPE Indeks, który służy do diagnozowania różnych aspektów pełnionej roli opiekuna, jego sytuacji życiowej oraz relacji z podopiecznym. Do pomiaru sprawności funkcjonalnej pacjentów wykorzystano skalę Barthel, a do oceny sprawności umysłowej skróconą wersję Testu sprawności umysłowej.
Wyniki: Obciążenie opiekuna wg COPE Indeks w poszczególnych subskalach wynosiło: w negatywnym wpływie opieki (NWO) 11,80 (SD = 3,75), w pozytywnej wartości opieki (PWO) - 13,71 ( $S D=2,07)$, w jakości wsparcia (JW) - 12,46 (SD = 2,69). Wykazano, że wraz z pogorszeniem się sprawności funkcjonalnej i umysłowej pacjentów istotnie wzrasta wśród opiekunów przeciążenie opieką - NWO $(\mathrm{p}<0,01)$, maleje satysfakcja z opieki - PWO $(\mathrm{p}<0,01)$ i obniża się jakość doświadczanego wsparcia - JW $(\mathrm{p}<0,01)$. Pogorszenie się stanu umysłowego pacjenta koreluje z płcią żeńską opiekuna i z dłuższym czasem sprawowanej opieki. Wnioski: Mniejsza sprawność funkcjonalna i umysłowa pacjentów objętych pielęgniarską opieką długoterminową domową ma związek z odczuwaniem przez opiekunów nieformalnych negatywnych skutków opieki, mniejszą satysfakcją ze sprawowanej opieki i obniżeniem jakości doświadczanego wsparcia. Słowa kluczowe: obciążenie; opiekun; opieka domowa; pacjent; deficyt sprawności. 


\section{WSTĘP}

Rodzina i jej członkowie jako opiekunowie nieformalni są najpowszechniejszym i najważniejszym dostawcą usług opiekuńczych w Polsce pomimo wsparcia, jakie otrzymuje pacjent, z zakresu pielęgniarskiej opieki długoterminowej domowej $[1,2]$.

Pielęgniarska opieka długoterminowa domowa to opieka nad obłożnie i przewlekle chorym przebywającym w domu. Może nią być objęty pacjent, który nie wymaga leczenia $\mathrm{w}$ warunkach stacjonarnych, jednak ze względu na istniejące problemy zdrowotne potrzebuje systematycznej i intensywnej opieki pielęgniarskiej w warunkach domowych. Tego rodzaju świadczeniami, finansowanymi ze środków publicznych, mogą być objęci pacjenci, którzy w ocenie skalą Barthel otrzymali 0-40 pkt i mają skierowanie od lekarza ubezpieczenia zdrowotnego [3, 4]. Ta forma opieki jest znacznie tańsza w porównaniu z zakładami stacjonarnymi opieki długoterminowej. Poza korzyściami finansowymi opieka domowa ma również pozytywny aspekt psychospołeczny, który przekłada się na lepsze samopoczucie pacjentów pozostających w domu oraz wpływa na więzi rodzinne [5].

Osobą, która najczęściej pełni rolę głównego opiekuna pacjenta, jest najbliższy członek rodziny. Inni krewni zwykle ograniczają się do udzielania wsparcia w różnym zakresie [6, 7].

Zapotrzebowanie na opiekę długoterminową świadczoną w środowisku chorego w Polsce, podobnie jak w większości innych krajów europejskich, jest coraz większe [8, 9]. Wiąże się z postępującym procesem starzenia się społeczeństwa oraz obniżaniem się wydolności opiekuńczej rodziny. Niska sprawność funkcjonalna i psychiczna pacjentów objętych opieką domową powoduje wzrost zapotrzebowania na świadczenie opieki zarówno formalnej, jak i nieformalnej sprawowanej $\mathrm{W}$ środowisku zamieszkania pacjenta $[10,11]$. Opieka nieformalna jest pojęciem szerszym niż opieka rodzinna, gdyż poza członkami rodziny zaangażowani mogą być znajomi, sąsiedzi, wolontariusze oraz osoby ze środowisk lokalnych [12]. Sprawowanie długotrwałej opieki nieformalnej nad pacjentem z małą sprawnością funkcjonalną pociąga za sobą wiele konsekwencji dla opiekunów w postaci obciążenia psychicznego, fizycznego i materialnego [13, 14]. Ograniczenia te pogarszają jakość życia opiekunów oraz wpływają na ich funkcjonowanie w obszarze społecznym, rodzinnym i zawodowym [15]. Opiekunowie rodzinni oraz inni opiekunowie nieformalni, którzy sprawują opiekę nad osobami bliskimi, są obciążeni licznymi obowiązkami, do których zalicza się m.in. zapewnienie profesjonalnych usług pielęgniarskich, transportowych, socjalnych i terapeutycznych [1]. Szeroki zakres obowiązków wykonywanych przez opiekunów nieformalnych na rzecz niesprawnych członków rodziny często staje się powodem ograniczenia przez nich wykonywanej pracy zawodowej [16] oraz wpływa na zwiększenie stresu i pogorszenie się stanu zdrowia $[17,18]$. Opiekunowie, którzy są w zawansowanym wieku, szczególnie współmałżonkowie, jak również ich dzieci (głównie córki), doświadczają największego obciążenia opieką [19, 20].

Celem pracy była ocena związku sprawności funkcjonalnej i stanu umysłowego pacjentów z chorobami przewlekłymi objętych pielęgniarską opieką długoterminową domową z obciążeniem opiekunów nieformalnych.

\section{MATERIAŁY I METODY}

Badania przeprowadzono w województwie lubelskim w okresie od września 2016 do lutego 2017 r. Grupę badanych stanowiło 149 pacjentów objętych pielęgniarską opieką długoterminową domową oraz 150 opiekunów nieformalnych. Dane od opiekunów i pacjentów zbierały pielęgniarki środowiskowe oraz opieki długoterminowej za pomocą standaryzowanych kwestionariuszy ankiety podczas wizyt domowych. Pielęgniarki były zatrudnione w 5 placówkach Podstawowej Opieki Zdrowotnej (4 znajdowały się na terenie miasta Lublina, a jedna była na obszarze wiejskim w okolicach Lublina).

Opiekunowie i pacjenci wyrazili pisemną zgodę na udział w badaniu, które zostało przeprowadzone zgodnie z zasadami Deklaracji helsińskiej. Procedura badawcza została zatwierdzona przez Komisję Bioetyczną Uniwersytetu Medycznego w Lublinie (nr KE-0254/13/2016).

Do oceny obciążenia opiekunów nieformalnych użyto kwestionariusza COPE Indeks, który służy do diagnozowania różnych aspektów pełnionej roli opiekuna, jego sytuacji życiowej oraz relacji z podopiecznym [21]. Narzędzie składa się z 3 podskal, które oceniają: negatywny wpływ opieki (NWO), pozytywną wartość opieki (PWO) oraz jakość wsparcia (JW). Kwestionariusz zawiera łącznie 15 pytań (NWO - 7, PWO - 4, JW - 4). Odpowiedzi na pytania oceniane są według 4-stopniowej skali Likerta: zawsze (4 pkt), często (3 pkt), czasami (2 pkt), nigdy (1 pkt).

Do pomiaru sprawności funkcjonalnej pacjentów wykorzystano skalę Barthel, która służy do oceny 10 podstawowych czynności życia codziennego: spożywania posiłków, przemieszczania się, utrzymania higieny osobistej, korzystania z toalety, kąpieli całego ciała, poruszania się po płaskiej powierzchni, wchodzenia po schodach, ubierania się, kontrolowania stolca i moczu [22]. Pacjent w zależności od zakresu samodzielności może otrzymać 0-100 pkt. Liczba uzyskanych punktów świadczy o stopniu niepełnosprawności i określa zapotrzebowanie na opiekę. Do oceny sprawności umysłowej pacjentów zastosowano polską wersję skróconego Testu sprawności umysłowej (Abbreviated Mental Test Score - AMTS), który składa się z 10 pytań. Użycie tego narzędzia pozwala na określenie zaburzeń funkcji poznawczych oraz stopnia ich nasilenia. Za poprawne udzielenie odpowiedzi lub wykonanie polecenia badany otrzymuje 1 pkt. Maksymalna liczba możliwych do uzyskania punktów wynosi 10, minimalna - 0. Na podstawie uzyskanego wyniku klasyfikuje się pacjentów do jednego z trzech stopni sprawności umysłowej [23].

\section{Analiza statystyczna}

Pozyskane dane poddano analizie statystycznej przy wykorzystaniu programu IBM SPSS Statistics. Zmienne zostały podsumowane przy użyciu standardowych statystyk opisowych, takich jak średnie (M), mediana (Md), odchylenia 
standardowe (SD) i częstotliwości. W celu ustalenia związku pomiędzy zmiennymi mierzonymi na skali ilościowej zastosowano współczynnik korelacji r Pearsona. Przed zastosowaniem tego współczynnika przeanalizowano rozkłady zmiennych: skośność i kurtoza mieściły się w przedziale $(-1 ; 1)$. W przypadku zmiennych porządkowych lub zmiennych, których rozkłady nie spełniały warunków zastosowania r Pearsona, zastosowano współczynnik korelacji rho Spearmana. Do ustalenia związku pomiędzy zmienną ilościową a zmienną dychotomiczną zastosowano współczynnik korelacji punktowo-biseryjnej. Przyjęto istotność statystyczną na poziomie $\mathrm{p}<0,05$.

\section{WYNIKI}

\section{Charakterystyka opiekunów nieformalnych}

Większość opiekunów stanowiły kobiety (75,3\%). Średni wiek badanych wynosił 57,69 lat ( $S D=12,9$ ), najmłodszy opiekun był w wieku 26 lat, a najstarszy - 84 lat. Największą grupę stanowiły osoby w wieku 56-65 lat (34,7\%). Opiekunów należących do najmłodszej grupy wiekowej 26-55 lat było 2-20\%. Najmniej liczną grupę tworzyli opiekunowie w wieku powyżej 65 lat $(6,7 \%)$. Zdecydowana większość badanych $(68,7 \%)$ deklarowała życie w związku małżeńskim/partnerskim.

Rolę opiekuna nieformalnego najczęściej pełniły dzieci osób objętych opieką domową $(46,7 \%)$ oraz współmałżonkowie (22\%), z kolei $15,5 \%$ opiekunów nie miało żadnego pokrewieństwa z pacjentem. Blisko $4 \%$ badanych opiekunów stanowili inni członkowie rodziny pacjentów.

Dla prawie połowy opiekunów (47,3\%) biernych zawodowo głównym źródłem dochodów była emerytura/renta oraz praca w pełnym $(34,6 \%)$ oraz niepełnym $(8 \%)$ wymiarze godzinowym. Najwięcej opiekunów (57,3\%) mieszkało razem z pacjentem $\mathrm{w}$ miejscu jego aktualnego pobytu, $12,7 \%$ dojeżdżało ok. 10 min środkiem lokomocji do pacjenta, a 11,3\% mieszkało w odległości krótkiego spaceru od miejsca zamieszkania podopiecznego.

\section{Charakterystyka pacjentów opieki domowej}

Rozpiętość wiekowa badanej grupy pacjentów wynosiła 58-104 lat, średnia wieku 74,91 (SD = 9,08). W większości były to osoby mieszkające w mieście (93,9\%), będące w stanie cywilnym wolnym (wdowy/wdowcy, osoby rozwiedzione) - 65,1\%. Wszyscy pacjenci byli objęci pielęgniarską opieką domową, z której średnio korzystali 3,59 lat (SD = 2,68).

Średnia liczba leków przepisanych przez lekarza przyjmowanych przez pacjentów wynosiła 7,9 (SD = 2,8). Badani pacjenci charakteryzowali się wielochorobowością, z dominacją chorób reumatologicznych $(77,9 \%)$, narządów zmysłów $(65,1 \%)$, psychiatrycznych (51,7\%) i endokrynologicznych (45\%).

Pacjenci objęci pielęgniarską opieką domową z deficytem sprawności funkcjonalnej i umysłowej otrzymali wg skali Barthel 0-85 pkt, a wg AMTS - 0-10 pkt. Średnie ocen sprawności funkcjonalnej i umysłowej w grupie ankietowanych wynosiły: wg Barthel - M = 43,20 (SD = 27,06), a wg AMTS $\mathrm{M}=7,78$ (SD = 2,64). Wśród badanych było 76,5\% kobiet oraz 23,5\% mężczyzn. Najliczniejszą grupę 68 (45,6\%) osób w ocenie skalą Barthel stanowili pacjenci z niską (21-40 pkt) oraz bardzo niską (0-20 pkt) sprawnością funkcjonalną - 49 osób (32,9\%). Pacjentów z umiarkowaną sprawnością funkcjonalną (41-85 pkt) było 21,5\% (32 osoby).

\section{Obciążenie opiekunów nieformalnych wedtug COPE Indeks}

Oceny obciążenia opiekunów nieformalnych dokonano oddzielnie dla każdej z analizowanych subskal COPE Indeks. Mediana w domenie NWO równa 11 pkt dała podstawę do dychotomizacji opiekunów na grupę mniej (7-10 pkt) i bardziej (11-28 pkt) obciążonych opieką. W domenie PWO mediana 14 pkt pozwoliła na wyodrębnienie opiekunów o niższym (4-13 pkt) i wyższym (14-16 pkt) wskaźniku PWO. W domenie JW mediana 13 pkt posłużyła do dychotomizacji opiekunów na grupę o niższym (4-12 pkt) i wyższym (13-16 pkt) wskaźniku jakości wsparcia.

W obszarze NWO wartość M wyniosła 11,80 (SD = 3,75), co świadczy o większym odczuwanym obciążeniu przez opiekuna sprawowaną opieką nad pacjentem, natomiast wyniki w domenach PWO wynoszące 13,71 (SD = 2,07) i w JW - 12,46 ( $\mathrm{SD}=2,69$ ) dowodzą, że pomimo negatywnego wpływu opieki opiekunowie nieformalni czerpią pozytywne korzyści z jej sprawowania. Wyniki przedstawiono w tabeli 1.

Przeprowadzona analiza wyników badań wskazała, że wraz z pogorszeniem się sprawności funkcjonalnej i umysłowej pacjentów istotnie wzrasta wśród opiekunów przeciążenie opieką - NWO ( $\mathrm{p}<0,01)$, maleje satysfakcja z opieki - PWO $(\mathrm{p}<0,01)$ i obniża się jakość doświadczanego wsparcia - JW $(\mathrm{p}<0,01)$. Wyniki przedstawiono $\mathrm{w}$ tabeli 2 .

Wraz z obniżeniem się sprawności funkcjonalnej istotnie wydłuża się średni czas sprawowanej opieki przez opiekuna nieformalnego $(\mathrm{p}<0,01)$ oraz wzrasta zapotrzebowanie na wsparcie ze strony innych osób $(\mathrm{p}<0,05)$. Pogorszenie się stanu umysłowego pacjenta koreluje z płcią żeńską opiekuna i wydłużeniem się czasu sprawowanej opieki. Wyniki przedstawiono w tabeli 3.

TABELA 1. Obciążenie opiekuna w poszczególnych subskalach COPE Indeks

\begin{tabular}{lccccc}
\multicolumn{1}{c}{$\begin{array}{c}\text { Subskale } \\
\text { COPE Indeks }\end{array}$} & $\begin{array}{c}\text { Zakres punktowy } \\
\text { subskali }\end{array}$ & $\begin{array}{c}\text { Średnia } \\
(\mathbf{M})\end{array}$ & $\begin{array}{c}\text { Mediana } \\
(\text { Me) }\end{array}$ & SD & Min. \\
\hline Negatywny wpływ opieki & $7-28$ & 11,80 & 11,00 & 3,75 & 23,00 \\
\hline Pozytywna wartość opieki & $4-16$ & 13,71 & 14,00 & 2,07 & 7,00 \\
\hline Jakość wsparcia & $4-16$ & 12,46 & 13,00 & 2,69 & 16,00 \\
\hline
\end{tabular}


TABELA 2. Sprawność funkcjonalna i umystowa pacjentów a obciążenie opiekuna w subskalach COPE Indeks

\begin{tabular}{lcc}
\multicolumn{1}{c}{ Subskale COPE Indeks } & Skala Barthel & Skala AMTS \\
\hline $\begin{array}{l}\text { Negatywny wpływ opieki } \\
\text { COPE }\end{array}$ & $-0,548^{*}$ & $-0,482^{*}$ \\
\hline $\begin{array}{l}\text { Pozytywna wartość opieki } \\
\text { COPE }\end{array}$ & $0,228^{*}$ & $0,430^{*}$ \\
\hline $\begin{array}{l}\text { Jakość wsparcia } \\
\text { COPE }\end{array}$ & $0,447^{*}$ & $0,470^{*}$ \\
\hline
\end{tabular}

* korelacja istotna na poziomie 0,01; AMS - Test sprawności umysłowej

TABELA 3. Sprawność funkcjonalna i umysłowa pacjentów a zmienne socjodemograficzne opiekuna, czas opieki nad pacjentem i wsparcie innych osób w opiece

\begin{tabular}{lcc}
\multicolumn{1}{c}{ Wybrane zmienne } & Skala Barthel & Skala AMTS \\
\hline Płeć opiekuna & 0,132 & $0,212^{*}$ \\
\hline Wiek opiekuna & $-0,016$ & $-0,08$ \\
\hline Stan cywilny opiekuna & 0,072 & 0,055 \\
\hline Czas opieki opiekuna & $-0,401^{*}$ & $-0,306^{*}$ \\
\hline Czas opieki innej osoby & $-0,16$ & $-0,173$ \\
\hline Wsparcie w opiece innej osoby & $-0,219^{* *}$ & $-0,145$ \\
\hline
\end{tabular}

* korelacja istotna na poziomie 0,01; ** korelacja istotna na poziomie 0,05; AMS - Test sprawności umysłowej

\section{DYSKUSJA}

Wyniki przeprowadzonych badań potwierdzają, że rodzina i jej członkowie są nadal bardzo ważnym dostawcą usług opiekuńczych dla chorych przebywających w środowisku domowym. Wykazano, że rolę opiekuna nieformalnego najczęściej pełniły dzieci pacjentów objętych opieką domową oraz współmałżonkowie, z czego zdecydowaną większość stanowiły kobiety. Sytuacja ta może mieć związek z nadumieralnością mężczyzn we wszystkich grupach wiekowych oraz dłuższą średnią życia kobiet [24].

W analizowanej literaturze wielu autorów podkreśla fakt, że wśród opiekunów osób w podeszłym wieku przeważają kobiety. U Karczewskiej i wsp. kobiety - opiekunki stanowiły $87,1 \%$ badanych [25], u Piłat - 62,5\% [26], u Bień i wsp. 79,7\% [27], natomiast u Zysnarskiej i wsp. 80,17\% [28].

Przeprowadzone badania wykazały, że wraz z pogorszeniem się sprawności funkcjonalnej i umysłowej podopiecznych wzrasta przeciążenie opiekunów rodzinnych oraz zapotrzebowanie na wsparcie ze strony innych osób. Badacze z europejskiego projektu EUROFAMCARE, stwierdzili, że „o ile satysfakcja z opieki nie zmienia się zależnie od poziomu niesprawności chorego, to obciążenie związane z wykonywaniem czynności opiekuńczych istotnie wzrasta wraz z pogorszeniem się stanu zdrowia i sprawności podopiecznego" [29].

Wykazano również, że opiekunowie nieformalni pomimo negatywnego obciążenia opieką w związku ze spadkiem sprawności funkcjonalnej podopiecznego wyrażają pozytywne odczucia w zakresie sprawowanej wartości opieki i jakości doświadczanego wsparcia. Do podobnego wniosku doszli inni badacze. Wojszel w swoich badaniach stwierdziła, że 44,9\% opiekunów na wsi i 57,3\% w mieście często lub czasami czuło się przeciążonych obowiązkami opiekuńczymi. Wśród nich 79,4\% w mieście i aż 90,1\% na wsi co najmniej czasami odczuwało satysfakcję z pełnionej opieki [29]. Grochowska wykazała, że zadowolenie z opieki czasami odczuwało 95\% opiekunów [30]. Według Cohen 73\% opiekunów stwierdziło, że miało pozytywne doświadczenia w opiece nad chorym. Ankietowani odczuwali poczucie spełnienia, ważności i odpowiedzialności oraz zadowolenia z nawiązania bliższej relacji z podopiecznym. Zgłaszali także mniej objawów depresyjnych wynikających z obciążenia opieką [31].

W związku ze wzrostem populacji osób starszych z mniejszą sprawnością funkcjonalną w Polsce zwiększa się potrzeba wprowadzenia odpowiednich rozwiązań systemowych, które wspierałyby edukacyjnie i psychologicznie opiekunów nieformalnych. Właściwe rozwiązania systemowe ukierunkowane na zmniejszenie obciążenia opiekunów sprawujących opiekę nad chorymi w domach mogą przyczynić się do wzrostu wydolności opiekuńczej rodzin, odraczając w ten sposób konieczność delegowania opieki do instytucji i zmniejszając wydatki na ten cel z budżetu państwa [32].

\section{WNIOSKI}

Opiekunowie nieformalni wg COPE-Indeks pomimo odczuwania negatywnych skutków opieki nad pacjentem (NWO) doświadczają pozytywnej wartości sprawowanej opieki (PWO) i jakości otrzymywanego wsparcia (JW).

Pogorszenie się sprawności funkcjonalnej i umysłowej pacjentów istotnie zwiększa obciążenie opiekunów, zmniejsza satysfakcję z opieki i obniża jakość doświadczanego wsparcia.

Pogorszenie się stanu umysłowego pacjenta koreluje z płcią żeńską opiekunów, dłuższym czasem sprawowanej opieki i zapotrzebowaniem na wsparcie świadczone przez inne osoby niezwiązane stopniem pokrewieństwa z podopiecznym.

\section{PIŚMIENNICTWO}

1. Borowiak E, Kostka T. Comparative characteristics of home care nursing services used by community-dwelling older people from urban and rural environments. J Adv Nurs 2013;69(6):1259-68. doi: 10.1111/j.13652648.2012.06113.x.

2. Ziembicka DM, Marcinowicz L. Pielęgniarska opieka długoterminowa domowa - stan polskich badań naukowych. Fam Med Primary Care Rev 2015;17(3):232-6. doi: 10.5114/fmpcr/58646.

3. Zarządzenie Nr 69/2014/DSOZ Prezesa NFZ z dnia 6.11.2014 r. w sprawie określenia warunków zawierania i realizacji umów w rodzaju: świadczenia pielęgnacyjne i opiekuńcze w ramach opieki długoterminowej. http://www.nfz.gov.pl/zarzadzenia-prezesa/zarzadzenia-prezesa-nfz/ zarzadzenie-nr-692014dsoz,6336.html (18.05.2018).

4. Kędziora Kornatowska K, Muszalik M, Skolmowska E, editors. Pielęgniarstwo w opiece długoterminowej. Warszawa: PZWL; 2015.

5. Kilańska D. Pielęgniarki liderkami opieki długoterminowej. Probl Pielęg 2010;18(1):72-8.

6. Marczak M, Tasak A. Oczekiwania pacjentów i ich opiekunów wobec systemu opieki nad przewlekle chorymi realizowanej w warunkach domowych. Polit Zdrow 2008/2009:77-81. 
7. Kosińska M, Kułagowska E, Niebrój L, Stanisławczyk D. Obciążenia opiekunów osób zakwalifikowanych do opieki długoterminowej domowej. Med Środow 2013;16(2):59-68.

8. Błędowski P, Maciejasz M. Rozwój opieki długoterminowej w Polsce stan i rekomendacje. Now Lek 2013;82(1):61-9.

9. Genet N, Boerma W, Kroneman M, Hutchinson A, Saltman RB, editors. Home care across Europe. Current structure and future challenges. Observatory Studies Series 2012;27:2-10. http://www.euro.who.int/_data/ assets/pdf_file/0008/181799/e96757.pdf (4.01.2018).

10. Markiewicz I, Cebulak M. Sprawność funkcjonalna pacjentów objętych domową długoterminową opieką pielęgniarską. Probl Pielęg 2014 22(1):42-51.

11. Cebulak M, Markiewicz I, Guty E. Ocena funkcji poznawczych u chorych objętych domową długoterminową opieką pielęgniarską. Probl Pielęg 2014; 22(1):20-6.

12. Strzelecka E. Szkolenie opiekunów osób starszych wobec nowych wyzwań na rynku pracy. Folia Oecon 2015;312(2):127-50.

13. Grabowska-Fudala B, Jaracz K, Smelkowska A, Pniewska J, Buczkowska M. Obciążenie osób sprawujących opiekę nad osobami z chorobą Alzheimera. Wyniki wstępne. Now Lek 2013;82(1):25-30.

14. Ganapathy V, Graham GD, DiBonaventura MD, Gillard PJ, Goren A, Zorowitz RD. Caregiver burden, productivity loss, and indirect costs associated with caring for patients with poststroke spasticity. Clin Interv Aging 2015;6(10):1793-802. doi: 10.2147/ CIA.S91123.

15. Pinquart M, Sörensen S. Differences between caregivers and noncaregivers in psychological health and physical health: a meta-analysis. Psychol Aging 2003;18(2):250-67.

16. Principi A, Lamura G, Sirolla C, Mestheneos L, Bień B, Brown J, et al. Work restrictions experienced by midlife family caregivers of older people. Ageing Soc 2014;34(2):209-31. doi: 10.1017/S0144686X12000967.

17. Kim H, Chang M, Rose K, Kim S. Predictors of caregiver burden in caregivers of individuals with dementia. J Adv Nurs 2012;68(4):846-55. doi: 10.1111/j.1365-2648.2011.05787.x.

18. Bauer JM, Sousa-Poza A. Impacts of informal caregiving on caregiver employment, health, and family. J Popul Ageing 2015;8(3):113-45. doi: 10.1007/s12062-015-9116-0.

19. Brazil K, Thabane L, Foster G, Bédard M. Gender differences among Canadian spousal caregivers at the end of life. Health Soc Care Community 2009;17(2):159-66. doi: 10.1111/j.1365-2524.2008.00813.x.
20. Sequeira C. Difficulties, coping strategies, satisfaction and burden in informal Portuguese caregivers. J Clin Nurs 2013;22(3-4):491-500. doi: 10.1111/ jocn.12108.

21. Balducci C, Mnich E, McKee KJ, Lamura G, Beckmann A, Krevers B, et al. Negative impact and positive value in caregiving: validation of the COPE index in a six-country sample of carers. Gerontologist 2008;48(3): 276-86.

22. Mahoney FI, Barthel DW. Functional evaluation: The Barthel Index. Md State Med J 1965;14:61-5.

23. Romanik W, Nazarewicz Ł. Wersja polska skróconego testu sprawności umysłowej (AMTS) problemy metodologiczne. Psychiatr Psychol Klin 2017;17(3):203-7.

24. Ludność w wieku 60+. Struktura demograficzna i zdrowie. GUS. https:// stat.gov.pl/obszary-tematyczne/ludnosc/ludnosc/ludnosc-w-wieku-60struktura-demograficzna-i-zdrowie,24,1.html (4.01.2018).

25. Karczewska B, Bień B, Ołdak E, Jamiołkowski J. Opiekunowie rodzinni osób starszych z otępieniem lub zaburzeniami poznawczymi w Polsce czynniki ryzyka obciążenia opieką. Gerontol Pol 2012;20(2):59-67.

26. Piłat A. Rodzinni opiekunowie osób starszych. Zesz Pracy Soc 2016;21(1):23-33. doi: 10.4467/24496138PS.16.003.6004.

27. Bień B, Wojszel ZB, Doroszkiewicz H. Poziom niesprawności osób w starszym wieku jako wskazanie do wspierania opiekunów rodzinnych. Gerontol Pol 2008;16(1):25-34.

28. Zysnarska M, Wojnicz-Michera I, Taborowska M, Kołecki P, Maksymiuk T. Kobieta- opiekun osoby przewlekle chorej - wyznaczniki przeciążenia. Now Lek 2010;79(5):386-91.

29. Wojszel ZB. Geriatryczne zespoły niesprawności i usługi opiekuńcze w późnej starości. Analiza wielowymiarowa na przykładzie wybranych środowisk województwa podlaskiego. Praca habilitacyjna. Białystok: Wyd. Uniwersytecki Trans Humana; 2009. p. 88.

30. Grochowska J. Poczucie satysfakcji oraz obciążenia obowiązkami nieformalnych opiekunów osób starszych w zależności od poziomu sprawności podopiecznych. Med Og Nauk Zdr 2014;20(1):46-50.

31. Cohen CA, Colantonio A, Vernich L. Positive aspects of caregiving: rounding out the caregiver experience. Int J Geriatr Psychiatry 2002;17(2):1848. http://dx.doi.org/10.1002/gps.561.

32. Ciałkowska-Kuźmińska M, Kasprzak M. Obciążenie opiekunów jako czynnik delegowania opieki do instytucji psychogeriatrycznych. Psychogeriatria Pol 2012;9(2):69-76. 